\title{
Fruit flies (Diptera: Tephritidae) in commercial mango orchards in a semiarid region of Brazil
}

\author{
Marcia Mayara de Sousa ${ }^{1}$, Elton Lucio Araujo ${ }^{2}$, Janisete Gomes Silva ${ }^{3}$, \\ Douglas Rafael Silva Barbosa ${ }^{4}$, Elania Clementino Fernandes ${ }^{5}$
}

Abstract - Fruit flies (Diptera: Tephritidae) are important mango (Mangifera indica L.) pests in
several parts of the world. Therefore, the main objective of this study was to know the species
of fruit flies associated with commercial mango orchards in a semiarid region of Rio Grande
do Norte state, Brazil; report the species of quarantine importance; discuss the influence of the
semiarid environment on the distribution of the species and verify their faunistic indices. The
study was carried out between July 2011 and June 2014 in ten commercial orchards of mango
cultivar Tommy Atkins in the semiarid region of the state of Rio Grande do Norte, Northeastern
Brazil. Fruit flies were captured in McPhail traps baited with $5 \%$ hydrolyzed corn protein (Bio
Anastrepha ${ }^{\circledR}$ ). Mangoes fruits were also collected. Faunistic analysis was performed to characterize
the populations. Eight fruit fly species (Anastrepha spp. and C. capitata) were captured. The species
C. capitata had the highest geographic distribution and was the only one to infest mangoes. The
faunistic analysis showed that most of the orchards had low species richness and that C. capitata
was the most frequent and predominant species.
Index terms: Frugivorous flies. Mangifera indica. Caatinga biome.
Moscas-das-frutas (Diptera: Tephritidae) em pomares
comerciais de mangueira, em uma
região semiárida do Brasil

Resumo - As moscas-das-frutas (Diptera: Tephritidae) são importantes pragas de mangueira (Mangifera indica L.) em várias partes do mundo. Portanto, o principal objetivo deste estudo foi conhecer as espécies de moscas-das-frutas associadas a pomares comerciais de mangueira em uma região semiárida do Estado do Rio Grande do Norte, Brasil; relatar as espécies de importância quarentenária; discutir a influência do semiárido na distribuição das espécies; e verificar seus índices

Corresponding author: marciamayarasos@gmail.com

Received: February 25, 2019 Accepted: August 12, 2019

Copyright: All the contents of this journal, except where otherwise noted, is licensed under a Creative Commons Attribution License.

\section{(cc) $\mathbf{E Y}$} faunísticos. O estudo foi realizado no período de julho de 2011 a junho de 2014, em dez pomares comerciais de mangueira da cultivar Tommy Atkins, localizados no semiárido do Estado do Rio Grande do Norte, região Nordeste do Brasil. As moscas-das-frutas foram capturadas com auxílio de armadilhas McPhail plásticas, tendo como atrativo proteína hidrolisada de milho a 5\% (Bio Anastrepha $\left.{ }^{\circledR}\right)$. Coletas de frutos de manga também foram realizadas. Uma análise faunística foi realizada para caracterizar as comunidades. Oito espécies de moscas-das-frutas (Anastrepha spp. e C. capitata) foram capturadas. A espécie C. capitata apresentou a maior distribuição geográfica e foi a única que infestou frutos de manga. A análise faunística mostrou que a maioria dos pomares apresentaou baixa riqueza de espécies, e $C$. capitata foi a mais frequente e predominante nos pomares.

Termos para indexação: Moscas frugívoras. Mangifera indica. Bioma Caatinga. 


\section{Introduction}

Mango (Mangifera indica L.) is one of the most cultivated and traded tropical fruits in the world. In Brazil, the largest planted area (45,000 hectars) and 75\% of fresh mango export is concentrated in the Northeastern region $(\mathrm{ABF}, 2017)$. Edaphoclimatic conditions in that region and advanced cultivation techniques (i.e. localized irrigation and floral induction) promote mango cultivation. Moreover, approximately $70 \%$ of the Brazilian Northeast is semiarid and comprises the Caatinga biome with several xerophytic and deciduous plant species, which are not proper hosts for fruit flies (ARAUJO et al., 2005).

Part of the Brazilian mango production is not exported due to quarantine restrictions of importing countries. Several countries around the world consider some fruit flies (Diptera: Tephritidae) species as pests of economic and quarantine importance (MEYER et al., 2010; VILLIERS et al., 2013; QIN et al., 2015). In Brazil, fruit fly species of economic and quarantine importance belong to the genus Anastrepha Schiner and Ceratitis Macquart, with the latter being represented only by Ceratitis capitata (Wiedemann) (ZUCCHI, 2015; ZUCCHI, 2017). The species C. capitata, Anastrepha obliqua (Macquart) and Anastrepha fraterculus (Wiedemann) are considered the most important fruit flies that infesting mango in Brazil (MALAVASI et al., 2000; ZUCCHI, 2015).

The success of fruit fly integrated management programs in commercial orchards depends on the knowledge of ecological aspects of these tephritids, such as diversity of species found in orchards and their faunistic indices (i.e. frequency, dominance, and constancy) (AGUIAR-MENEZES et al., 2008; SÁ et al., 2012; ARAUJO et al., 2013). In tropical environments, factors such as climate and type of local vegetation might influence the diversity and faunistic indices of fruit fly populations in orchards (SÁ et al., 2012).

Despite the relevance of mango cultivation for Brazil and economic and quarantine importance of fruit flies, information on the association of these tephritids with commercial mango orchards in semiarid conditions in Brazil is still scarce. Therefore, the main objective of this study was to know the species of fruit flies associated with commercial mango orchards in a semiarid region in the state of Rio Grande do Norte, Brazil; report the species of quarantine importance; discuss the influence of the semiarid environment on the distribution of the species; and verify their faunistic indices. The results of this study will expand the knowledge on fruit fly ecology in the semiarid and also contribute to improve the integrated management of fruit fly in commercial mango orchards in the region.

\section{Material and Methods}

The study was carried out from July 2011 to June 2014 in ten commercial orchards of mango cultivar Tommy Atkins in the Brazilian semiarid region (Caatinga biome) (Figure 1). These orchards are located in the municipalities of Afonso Bezerra (MLS orchard), Assu (PTO orchard), Baraúna (PRV, CST and VLM orchards), Ipanguaçu (SJO, SFC and UBN orchards), Mossoró (PLC orchard), and Rio do Fogo (SAT orchard), state of Rio Grande do Norte (Table 1). The evaluated orchards belong to the same company and were submitted to the same cultural treatments and phytosanitary management. In the orchards, pest monitoring was performed and insecticide applications were made only for the control of thrips and mites, according to infestation index in each orchard.

The dominant vegetation in the area is Caatinga, which mainly comprises xerophytic and deciduous plant species. The climate is predominantly hot semiarid (type BSh), characterized by scarce and irregular rain (600 $\mathrm{mm}$ annual mean rainfall), elevated mean temperatures ( \pm $\left.28^{\circ} \mathrm{C}\right)$, and low air humidity $( \pm 65 \%)$ (KÖPPEN, 1948).

Only in the municipality of Rio do Fogo the vegetation is a transition between the Caatinga and tropical rainforest. The climate is tropical wet (type As), which is characterized by the absence of summer rains, rainy season with annual rainfall indices of approximately $1,500 \mathrm{~mm}$, mean temperature of $\pm 26^{\circ} \mathrm{C}$ and mean air humidity of \pm $75 \%$ (KÖPPEN, 1948).

Fruit flies were captured using McPhail traps baited with 5\% hydrolyzed corn protein (Bio Anastrepha ${ }^{\circledR}$ ) with a trap density of one trap per ten ha (Table 1). Weekly, every trap was filled with $500 \mathrm{ml}$ of attractant solution and the captured insects were collected and transferred to plastic containers with $70 \%$ ethanol. Subsequently, the containers were taken to the laboratory and the fruit flies were identified.

Ripen mangoes were randomly collected in the commercial mango orchards, 40 fruits from each orchard, to verify which fruit fly species infest Tommy Atkins mangoes in the studied area. Collected fruits were taken to the laboratory, where they were counted and weighed. They were then placed on plastic trays over a layer of vermiculite and covered with voile cloth. After ten days, the vermiculite was sifted weekly and the pupae obtained were placed in plastic containers until adult emergence.

Anastrepha species were identified based on their wing pattern (wing bands), thoracic pattern, and mainly on the female genitalia. Ceratitis capitata was identified based on the characteristics of its wings as well as scutellar and postocular bristles.

Faunistic analysis was performed with information from the four orchards (SAT, SJO, MLS and PRV) that showed the highest numbers and diversity of fruit fly species captured. As male of fruit flies are not identified 
at species level, only the females were considered in the faunistic analysis, which was carried out using the software ANAFAU to characterize the populations regarding frequency, abundance, constancy, dominance, evenness, as well as Shannon-Wiener and Margalef diversity indices (SILVEIRA NETO et al., 1976; AGUIAR-MENEZES et al., 2008).

A dendrogram of similarity among the four orchards assessed, based on species composition and number of individuals collected, was generated via single-linkage hierarchical clustering analysis in the software program Systat 13.1, in which the similarity was compared using Euclidean distances.

\section{Results and Discussion}

A total of 4,525 fruit flies $(4,163$ Ceratitis and 362 Anastrepha) was collected in the ten commercial mango orchards studied. The species captured were C. capitata (91.34\%), Anastrepha dissimilis (Stone) (3.36\%), A. fraterculus (0.11\%), A. obliqua (1.91\%), Anastrepha pickeli (Lima) (0.04\%), Anastrepha serpentina (Wiedemann) (0.04\%), Anastrepha sororcula Zucchi $(2.75 \%$, ) and Anastrepha zenildae Zucchi (0.45\%) (Table 2). Ceratitis capitata was the only species captured in all ten orchards (Table 2).

The eight fruit fly species captured in this study are common in Brazil (ZUCCHI, 2017). The fact that C. capitata was captured in every orchard and usually in higher numbers shows that this species has a wide distribution in the region associated with the mango orchards. In other semiarid regions, C. capitata is also a common species (ALVARENGA et al., 2009; ARAUJO et al., 2013). It is noteworthy that among the fruit flies captured, C. capitata, A. dissimilis, A. obliqua, A. pickeli, A. sororcula, and A. zenildae are common in semiarid environments, contrary to $A$. fraterculus and $A$. serpentina, which show low frequency in the Brazilian semiarid region (MALAVASI et al., 2000) and are more common in more humid and forested areas in the Northeastern region (SILVA et al., 2010).

Ripen mangoes randomly collected in some of the orchards showed that only C. capitata infested mangoes in commercial orchards in the semiarid region in this study (Table 3). Due to the small number of studies involving collection of fruits in commercial mango orchards in the semiarid region in Brazil, the finding of C. capitata infesting mangoes helps confirm that this species is the main tephritid present in commercial mango cultivar Tommy Atkins orchards in the semiarid region of the Rio Grande do Norte state.

Even though A. obliqua and A. fraterculus are considered mango pests in Brazil, surveys carried out in the semiarid have shown absence or low infestation indices of these species in mangoes (ARAUJO et al., 2005; SÁ et al., 2008; ALVARENGA et al., 2009; ZUCCHI, 2017). In Brazil, most commercial mango orchards produce the cultivar Tommy Atkins, thus it is possible that the low fruit infestation indices are related to the lower preference of Anastrepha for this cultivar (GUILLÉN et al., 2017). Moreover, in the Brazilian semiarid region, A. obliqua prefers hosts in the genus Spondias - Anacardiaceae, mainly "umbu cajá" (Spondias sp.) and "umbu" (Spondias tuberosa Arruda), which are endemic to the Caatinga biome and have a wide distribution in the Caatinga vegetation (ARAUJO et al., 2005; ALVARENGA et al., 2009).

The fact that other Anastrepha species were not reared from mangoes is probably because most of them are stenophagous and prefer hosts in other families such as $A$. dissimilis in Passifloraceae, A. pickeli in Euphorbiaceae, A. serpentina in Sapotaceae, A. sororcula in Myrtaceae, and A. zenildae in Rhamnaceae and Myrtaceae (ZUCCHI, 2017).

The fruit flies of quarantine importance detected in the traps were $C$. capitata, A. obliqua, A. fraterculus and A. serpentina. In almost every orchard, C. capitata and $A$. obliqua were the only species of quarantine importance collected. Only in the SAT orchard, all four species of quarantine importance were captured. The presence of these species in production areas can be a hindrance to the export of fresh fruit (MALAVASI et al., 2000). However, the results show that for the semiarid region of Rio Grande do Norte, C. capitata is the most important species since it is common in the region and has been found infesting ripen mangoes. Even though $A$. obliqua is considered an important mango pest in the tropical America (FU et al., 2014; GUILLÉN et al., 2017) and it has a wide distribution in Brazil, this species has not been a problem in mango orchards in this region of the semiarid. The species $A$. fraterculus and A. serpentina should not cause great concern as they practically do not occur in the semiarid region (MALAVASI et al., 2000). Moreover, mango is not the preferred host of A. fraterculus, and $A$. serpentina has never been reported infesting mangoes in Brazil (ZUCCHI, 2017).

In the four mango orchards studied using faunistic analysis (SJO, MLS, PRV and SAT), a total of 1,849 females were captured $(1,644$ C. capitata and 205 Anastrepha spp.). In each one of the SJO, MLS and PRV orchards only three species were reported $(S=3)$ (Table 4). The highest richness was observed in the SAT orchard $(\mathrm{S}=7)$.

The low richness in the SJO, MLS, and PRV orchards is possibly due to the climate and vegetation of the semiarid that do not support a high richness of fruit flies by the lack of host fruits. The Caatinga vegetation is latent during most of the year and has few plants with fruits of fleshy pulp, which are potential hosts of fruit flies (ARAUJO et al., 2005). 
The higher richness found in the SAT orchard confirms the previous statement, since the orchard is located exactly in an area of transition between the Caatinga and Atlantic Rainforest biomes, where the climate is more favorable for fruit flies and the vegetation has higher diversity and host availability throughout the year. Moreover, Sá et al. (2012) reported the occurrence of eight Anastrepha species in mango orchards located in an area of transition between the Caatinga and the Cerrado biomes. Furthermore, in a survey carried out in a mango orchard located in the Atlantic Rainforest, the presence of 12 fruit fly species was observed (C. capitata and Anastrepha spp.) (MONTES et al., 2012).

Among the main species that infest mangoes in Brazil (C. capitata, A. obliqua and A. fraterculus), $C$. capitata was the most frequent and dominant in this study. Moreover, it was highly abundant in most orchards and constant in two of them (Table 4). Anastrepha obliqua showed low frequency and abundance, and it was considered non-dominant and accessory. Anastrepha fraterculus was found only in the SAT orchard and was considered non-dominant and accidental.

The dominance of $C$. capitata in mango orchards is related to its distribution in the region under study and to the fact that this species is the main tephritid exploring Tommy Atkins mangoes as a food resource in the semiarid environment (ARAUJO et al., 2005). This dominance is probably related to its invasive potential (SZYNISZEWSKA et al., 2014) and highly adaptable nature over other fruit fly species in commercial mango orchards in the region studied.

Although A. obliqua was the second most frequent species in the orchards, the faunistic indices obtained (low frequency, low abundance, non-dominant and accessory) indicate a weak association between A. obliqua and commercial mango orchards in the semiarid of the Rio Grande do Norte state. The faunistic indices for A. obliqua suggest that this tephritid infests other hosts in nearby the orchards and is attracted to the traps installed in the mango trees.

Anastrepha fraterculus also showed a weak association with the mango orchards and was captured only in the SAT orchard, which indicates that its distribution is possibly negatively influenced by the semiarid climate, as reported by Malavasi et al. (2000). Similarly to what was seen for A. obliqua, it is likely that $A$. fraterculus explores other hosts in the region and is attracted to the traps installed in the mango orchards. Therefore, even though A. fraterculus is a polyphagous species and dominant in several regions in Brazil (SILVA et al., 2010; GARCIA e NORRBOM, 2011; RAGA et al., 2011), it is not common in commercial mango orchards in the semiarid of the Rio Grande do Norte state.
Besides low species richness, most orchards showed low evenness $(E=0.04-0.30)$ and low diversity indices $\left(H^{\prime}\right.$ $=0.04-0.59 ; \alpha=0.34-0.85$ ). Only in the MLS orchard, higher evenness and diversity indices were observed (E $=0.82)\left(H^{\prime}=0.90 ; \alpha=0.96\right)($ Table 4$)$. The low evenness in the orchards is due to the high number of $C$. capitata trapped relative to other species, as observed by Dutra et al. (2009). The low diversity indices observed in the orchards were influenced by the richness and evenness values according to Aguiar-Menezes et al. (2008). Aluja et al. (1996) also observed low Margalef diversity indices $(\alpha=0.3-1.3)$ in commercial mango orchards in Mexico, where only two species were dominant.

In general, commercial orchards show low indices of evenness and diversity of fruit flies when compared with domestic orchards and forest areas. This happens due to the homogeneity of the fruit trees in commercial orchards, which does not allow the maintenance of high populations of different fruit fly species and results in a higher number of individuals from only one or two species (ALUJA et al., 1996). The same was seen with C. capitata in this study.

The dendrogram of similarity (Euclidean distance) among the orchards, based on species composition and number of individuals collected, showed two clusters with one of comprising SJO, MLS, and PRV orchards and other only the SAT orchard (Figure 2). The two clusters in the dendrogram of similarity demonstrated that the SJO, MLS and PRV orchards were highly similar relative to the SAT orchard. Since the SJO, MLS and PRV orchards are under similar climate and surrounding vegetation (Caatinga biome) the isolation of the SAT orchard in the dendrogram supports the statement that its location, an area of transition between the Caatinga and Atlantic Rainforest biomes, influenced the diversity and number of species trapped. Sá et al. (2012) carried out an analysis of similarity of fruit flies in Tommy Atkins mango orchards in a semiarid region of Brazil and reported that the formation of clusters in the dendrogram was related to the diversity of host plants surrounding the orchards.

Although the semiarid does not allow high species diversity and large populations of fruit flies, our results showed that in commercial mango orchards located in the semiarid region of Rio Grande do Norte, the major concerns should be directed towards $C$. capitata due to its wide distribution and high frequency in this type of environment, its dominance, and for being the only one that infested mangoes even when ripen. 


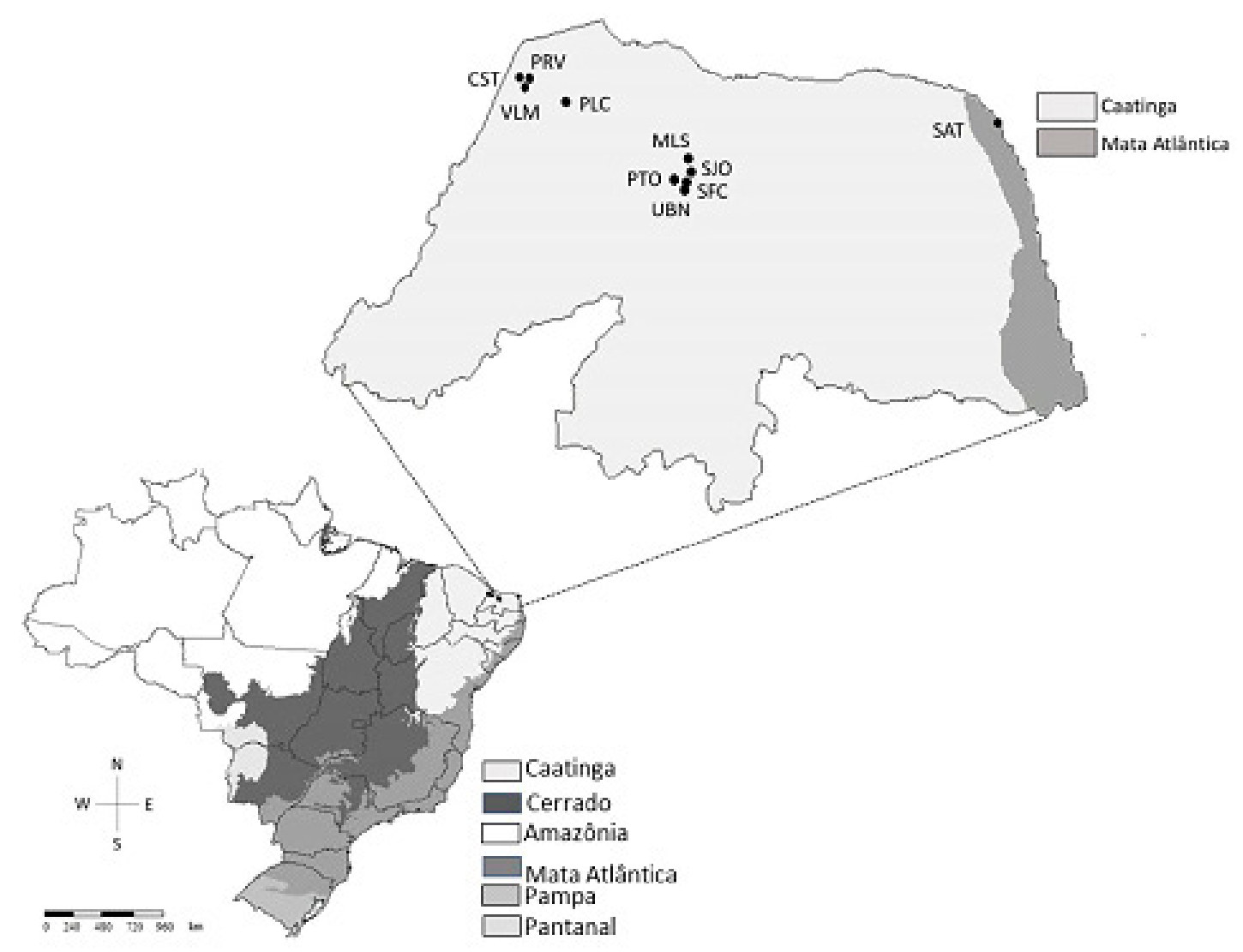

Figure 1 - Brazilian biomes and location of the ten commercial mango orchards studied in the state of Rio Grande do Norte, Brazil.

\section{Diagrammatic tree using the Euclidean distances}

\section{SAT Orchard}
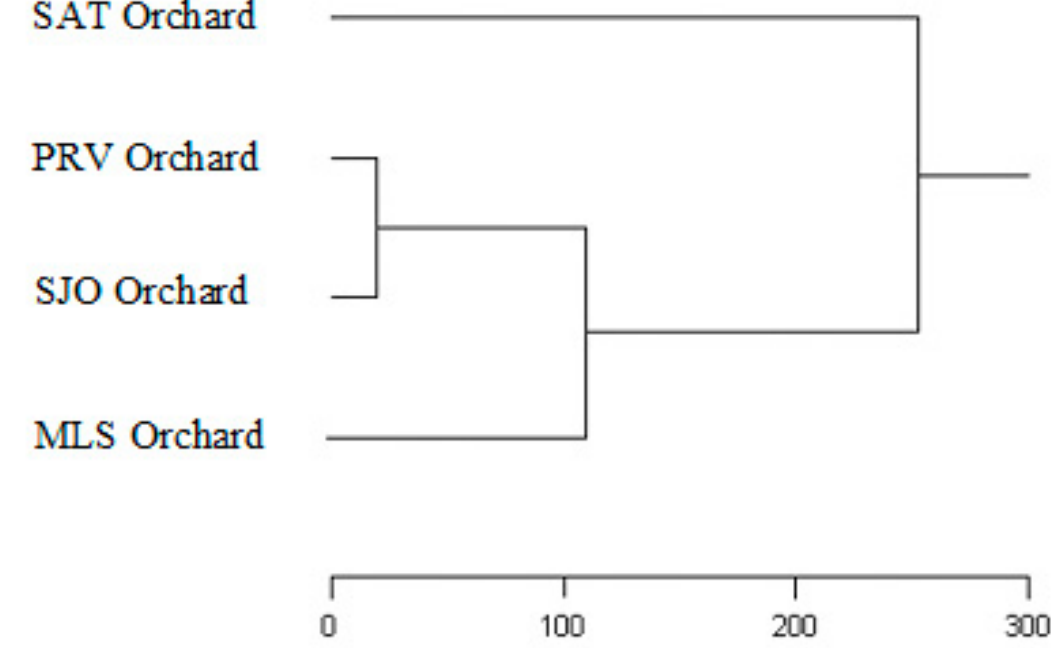

\section{Linkage distance}

Figure 2 - Dendrogram comparing the similarity of fruit fly species composition in commercial mango orchards (SAT, PRV, SJO, and MLS) from July 2011 to June 2014 in the semiarid region of the State of Rio Grande do Norte, Brazil. 
Table 1 - Location and number of traps set for capturing fruit flies in the commercial mango orchards from July 2011 to June 2014 in the semiarid region of the State of Rio Grande do Norte, Brazil.

\begin{tabular}{|c|c|c|c|}
\hline Municipalities & Orchards & Location & Number of traps \\
\hline Afonso Bezerra & MLS* & $5^{\circ} 25^{\prime} 60^{\prime \prime} \mathrm{S} / 36^{\circ} 50^{\prime} 38^{\prime \prime} \mathrm{W}$ & 5 \\
\hline Assu & PTO & $5^{\circ} 31^{\prime} 33^{\prime \prime} \mathrm{S} / 36^{\circ} 54^{\prime} 30^{\prime \prime} \mathrm{W}$ & 3 \\
\hline \multirow[t]{3}{*}{ Baraúna } & $\mathrm{PRV}^{*}$ & $5^{\circ} 05^{\prime} 17^{\prime \prime} \mathrm{S} / 37^{\circ} 35^{\prime} 49^{\prime \prime} \mathrm{W}$ & 4 \\
\hline & CST & $5^{\circ} 07^{\prime} 26^{\prime \prime} \mathrm{S} / 37^{\circ} 37^{\prime} 19^{\prime \prime} \mathrm{W}$ & 3 \\
\hline & VLM & $5^{\circ} 04^{\prime} 51^{\prime \prime} \mathrm{S} / 37^{\circ} 38^{\prime} 54^{\prime \prime} \mathrm{W}$ & 2 \\
\hline \multirow[t]{3}{*}{ Ipanguaçu } & SJO* & $5^{\circ} 31^{\prime} 40^{\prime \prime} \mathrm{S} / 36^{\circ} 52^{\prime} 09^{\prime \prime} \mathrm{W}$ & 11 \\
\hline & SFC & $5^{\circ} 32^{\prime} 16^{\prime \prime} \mathrm{S} / 36^{\circ} 52^{\prime} 14^{\prime \prime} \mathrm{W}$ & 5 \\
\hline & UBN & $5^{\circ} 29^{\prime} 15^{\prime \prime} \mathrm{S} / 36^{\circ} 50^{\prime} 06^{\prime \prime} \mathrm{W}$ & 22 \\
\hline Mossoró & PLC & $5^{\circ} 11^{\prime} 25^{\prime \prime} \mathrm{S} / 37^{\circ} 25^{\prime} 17^{\prime \prime} \mathrm{W}$ & 4 \\
\hline Rio do Fogo & $\mathrm{SAT}^{*}$ & $5^{\circ} 16^{\prime} 22^{\prime \prime} \mathrm{S} / 35^{\circ} 22^{\prime} 58^{\prime \prime} \mathrm{W}$ & 13 \\
\hline
\end{tabular}

* Orchards used in the faunistic analysis.

Table 2 - Species and number of fruit fly captured in the commercial mango orchards from July 2011 to June 2014 in the semiarid region of the State of Rio Grande do Norte, Brazil.

\begin{tabular}{|c|c|c|}
\hline Municipalities & Orchards & Species (number of fruit fly captured) \\
\hline Afonso Bezerra & MLS & Ceratitis capitata (5), Anastrepha obliqua (2) and A. zenildae (1) \\
\hline Assu & PTO & C. capitata (2), A. obliqua (1) and A. sororcula (1) \\
\hline \multirow[t]{3}{*}{ Baraúna } & PRV & C. capitata (343), A. obliqua (1) and A. sororcula (1) \\
\hline & CST & C. capitata (494), A. obliqua (1) and A. zenildae (1) \\
\hline & VLM & C. capitata (110) and A. obliqua (1) \\
\hline \multirow[t]{3}{*}{ Ipanguaçu } & SJO & C. capitata (294), A. obliqua (18) and A. zenildae (3) \\
\hline & SFC & C. capitata (3), A. obliqua (8) and A. zenildae (5) \\
\hline & UBN & C. capitata (58) and A. zenildae (1) \\
\hline Mossoró & PLC & C. capitata (82), A. obliqua (2) and A. pickeli (1) \\
\hline Rio do Fogo & SAT & $\begin{array}{l}\text { C. capitata }(1,002) \text {, A. obliqua }(16) \text {, A. zenildae }(1) \text {, A. fraterculus (3), } \\
\text { A. sororcula }(70) \text {, A. dissimilis }(88) \text { and A. serpentina }(1)\end{array}$ \\
\hline
\end{tabular}

Table 3 - Fruit flies reared from ripe mangoes collected in the commercial orchards located in the semiarid region of the State of Rio Grande do Norte, Brazil.

\begin{tabular}{|c|c|c|c|c|c|c|c|}
\hline \multirow{2}{*}{ Orchards } & \multirow{2}{*}{$\begin{array}{c}\mathrm{N}^{\circ} \text { of fruits } \\
\text { collected }\end{array}$} & \multirow{2}{*}{$\begin{array}{l}\text { Weight } \\
(\mathrm{Kg})\end{array}$} & \multicolumn{2}{|c|}{$\mathrm{N}^{\circ}$ of pupae } & \multirow{2}{*}{$\begin{array}{l}\text { Infestation } \\
\text { (Pupae/kg) }\end{array}$} & \multicolumn{2}{|c|}{$\mathrm{N}^{\circ}$ of adult fly } \\
\hline & & & C. capitata & Anastrepha spp. & & C. capitata & Anastrepha spp. \\
\hline PRV & 40 & 18.7 & 77 & 0 & 4.1 & 55 & 0 \\
\hline PTO & 40 & 15.9 & 0 & 0 & 0.0 & 0 & 0 \\
\hline SAT & 40 & 16.7 & 5 & 0 & 0.3 & 3 & 0 \\
\hline SJO & 40 & 18.2 & 14 & 0 & 0.8 & 8 & 0 \\
\hline MLS & 40 & 19.8 & 2 & 0 & 0.1 & 0 & 0 \\
\hline VLM & 40 & 18.9 & 66 & 0 & 3.5 & 63 & 0 \\
\hline
\end{tabular}


Table 4 - Faunistic analysis of the fruit flies captured using McPhail traps in four commercial mango orchards (SAT, SJO, MLS, and PRV) from July 2011 to June 2014 in the semi-arid region of the state of Rio Grande do Norte, Brazil.

\begin{tabular}{|c|c|c|c|c|c|c|c|c|c|c|c|c|c|c|c|c|c|}
\hline Species & \multicolumn{3}{|c|}{ SAT orchard } & \multicolumn{4}{|c|}{ SJO orchard } & \multicolumn{5}{|c|}{ MLS orchard } & \multicolumn{5}{|c|}{ PRV orchard } \\
\hline & $\mathrm{N}$ & $\mathrm{F} \quad \mathrm{A}$ & C D & $\mathrm{N}$ & $\mathrm{F}$ & $\mathrm{A}$ & C $\quad \mathrm{D}$ & $\mathrm{N}$ & $\mathrm{F}$ & A & $\mathrm{C}$ & $\mathrm{D}$ & $\mathrm{N}$ & $\mathrm{F}$ & $\mathrm{A}$ & $\mathrm{C}$ & D \\
\hline C. capitata & 1,002 & sf $\mathrm{sa}$ & w sd & 294 & hf & ha & $y \quad d$ & 5 & $\mathrm{f}$ & $\mathrm{c}$ & $\mathrm{y}$ & $\mathrm{d}$ & 343 & hf & ha & $\mathrm{w}$ & $\mathrm{d}$ \\
\hline A. dissimilis & 88 & hf ha & W d & 0 & - & - & - & 0 & - & - & - & - & 0 & - & - & - & - \\
\hline A. sororcula & 70 & hf ha & w d & 0 & - & - & - & 0 & - & - & - & - & 1 & f & ha & $\mathrm{y}$ & nd \\
\hline A. obliqua & 16 & f ha & $\mathrm{y}$ nd & 18 & $\mathrm{f}$ & ha & $\mathrm{y}$ nd & 2 & $\mathrm{f}$ & $\mathrm{c}$ & $\mathrm{y}$ & nd & 1 & $f$ & ha & $\mathrm{y}$ & nd \\
\hline A. fraterculus & 3 & f ha & $\mathrm{z}$ nd & 0 & - & - & - & 0 & - & - & - & - & 0 & - & - & - & - \\
\hline A. zenildae & 1 & f ha & $\mathrm{z}$ nd & 3 & $f$ & ha & y nd & 1 & $\mathrm{f}$ & $\mathrm{c}$ & $\mathrm{y}$ & nd & 0 & - & - & - & - \\
\hline A. serpentina & 1 & f ha & $\mathrm{z}$ nd & 0 & - & - & $-\quad-$ & 0 & - & - & - & - & 0 & - & - & - & - \\
\hline Total & 1,181 & & & 315 & & & & 8 & & & & & 345 & & & & \\
\hline S & 7 & & & 3 & & & & 3 & & & & & 3 & & & & \\
\hline $\mathrm{H}^{\prime}$ & 0.59 & & & 0.27 & & & & 0.90 & & & & & 0.04 & & & & \\
\hline E & 0.30 & & & 0.25 & & & & 0.82 & & & & & 0.04 & & & & \\
\hline$\alpha$ & 0.85 & & & 0.35 & & & & 0.96 & & & & & 0.34 & & & & \\
\hline
\end{tabular}

$\mathrm{N}=$ number of flies (female) captured; $\mathrm{F}=$ frequency: $\mathrm{sf}$ (super frequent), hf (highly frequent), $\mathrm{f}$ (frequent); $\mathrm{A}=$ abundance: sa (super abundant), ha (highly abundant), $\mathrm{c}$ (common); $\mathrm{C}=$ constancy: $\mathrm{w}$ (constant), y (accessory), $\mathrm{z}$ (accidental); $\mathrm{D}=$ dominance: sd (super dominant), $\mathrm{d}$ (dominant), nd (non-dominant); $\mathrm{S}=$ richness (number of species); $\mathrm{H}^{\prime}=$ Shannon-Wiener diversity index; $\mathrm{E}=$ evenness index; $\alpha=$ Margalef diversity index.

\section{Conclusions}

The results obtained demonstrate that eight fruit fly species ( $C$. capitata, A. dissimilis, A. fraterculus, $A$. obliqua, A. pickeli, A. serpentina, A. sororcula and $A$. zenildae) occur in the commercial Tommy Atkins mango orchards cultivated in the semiarid in the state of Rio Grande do Norte, Brazil.

Among the species that infest mango in Brazil, $C$. capitata, A. obliqua and A. fraterculus are the species of quarantine importance present in the commercial mango orchards evaluated.

The climate and vegetation of the semiarid influenced negatively the diversity of fruit flies in mango orchards.

The fruit fly $C$. capitata was the dominant species in the orchards, A. obliqua showed a weak association with the orchards and $A$. fraterculus a limited distribution.

\section{Acknowledgements}

We would like to thank Conselho Nacional de Desenvolvimento Científico e Tecnológico (CNPq) for granting a master scholarship to Marcia M. Sousa and a research scholarship to Janisete G. Silva and Elton L. Araujo. Thanks are also due to Comitê Executivo de Fruticultura do Rio Grande do Norte (COEX) for assisting with the collection of insects in the field.

\section{References}

ABF - Anuário Brasileiro da Fruticultura. Santa Cruz do Sul: Editora Gazeta, 2017. 92 p. Disponível em: http:// www.editoragazeta.com.br/flip/anuario-fruticultura-2017/ files/assets/basic-html/index.html\#1/. Acesso em: 18 jul. 2017.

AGUIAR-MENEZES, E.L.; SOUZA, S.A.S.; LIMAFILHO, M.; BARROS, H. C.; FERRARA, F.A.A.; MENEZES, E.B. Análise faunística de moscas-das-frutas (Diptera: Tephritidae) nas regiões Norte e Noroeste do Estado do Rio de Janeiro. Neotropical Entomology, Londrina, v.37, n.1, p. 8-14, 2008.

ALUJA, M.; CELEDONIO-HURTADO, H.; LIEDO, P.; CABRERA, M.; CASTILLO, F.; GUILLÉN, J.; RIOS, E. Seasonal population fluctuations and ecological implications for management of Anastrepha fruit flies (Diptera: Tephritidae) in commercial mango orchards in Southern Mexico. Journal of Economic Entomology, Lanham, v.89, n.3, p.654-667, 1996.

ALVARENGA, C.D.; MATRANGOLO, C.R.A.; LOPES, G.N.; SILVA, M.A.; LOPES, E.N.; ALVES, D.A.; NASCIEMNTO, A.S.; ZUCCHI, R. A. Moscasdas-frutas (Diptera: Tephritidae) e seus parasitóides em plantas hospedeiras de três municípios do norte do estado de Minas Gerais. Arquivos do Instituto Biológico, São Paulo, v.76, n.2, p. 195-204, 2009. 
ARAUJO, E.L.; MEDEIROS, M.K.M.; SILVA, V.E.; ZUCCHI, R.A. Moscas-das-frutas (Diptera: Tephritidae) no semi-árido do Rio Grande do Norte: plantas hospedeiras e índices de infestação. Neotropical Entomology, Londrina, v.34, n.6, p. 889-894, 2005.

ARAUJO, E.L.; RIBEIRO, J.C.; CHAGAS, M.C.M.; DUTRA, V.S.; SILVA, J.G. Moscas-das-frutas (Diptera: Tephritidae) em um pomar de goiabeira, no semiárido brasileiro. Revista Brasileira de Fruticultura, Jaboticabal, v.35, n.2, p.471-476, 2013.

DUTRA, V.S.; SANTOS, M.S.; SOUZA FILHO, Z.A.; ARAUJO, E.L.; SILVA, J.G. Faunistic analysis of Anastrepha spp. (Diptera: Tephritidae) on a guava orchard under organic management in the municipality of Una, Bahia, Brasil. Neotropical Entomology, Londrina, v.38, n.1, p.133-138, 2009.

FU, L.; ZHI-HONG, L.; GUAN-SHENG, H.; XINGXIA, W.; WEN-LONG, N.; WEI-WEI, Q. The current and future potential geographic range of West Indian fruit fly, Anastrepha obliqua (Diptera: Tephritidae). Insect Science, Beijing, v.21, n.2, p.234-244, 2014.

GARCIA, F.R.M.; NORRBOM, A.L. Tephritoid flies (Diptera, Tephritoidea) and their hosts from the state of Santa Catarina in Southern Brazil. Florida Entomologist, Winter Haven, v.94, n.2, p.151-157, 2011.

GUILLÉN, L.; ADAIME, R.; BIRKE, A.; VELÁZQUES, O.; ANGELES, G.; ORTEGA, F.; RUIZ, E.; ALUJA, M. Effect of resin ducts and sap contente on infestation and development of immature stages of Anastrepha obliqua and Anastrepha ludens (Diptera: Tephritidae) in four mango (Sapindales: Anacardiaceae) cultivars. Journal of Economic Entomology, Lanham, v.110, n.2, p. 719$730,2017$.

KÖPPEN, W. Climatologia: com un estudio de los climas de la Tierra. Pánuco: Fondo de Cultura Econômica, 1948. 478p.

MALAVASI, A.; ZUCCHI, R.A.; SUGAYAMA, R.L. Biogeografia. In: MALAVASI, A.; ZUCCHI, R.A. Moscas-das-frutas de importância econômica no Brasil: conhecimento básico e aplicado. Ribeirão Preto: Holos Editora, 2000. p. 93-98.

MEYER, M.D.; ROBERTSON, M.P.; MANSELL, M.W.; EKESI, S.; TSURUTA, K.; MWAIKO, W.; VAYSSIÈRES, J.F.; PETERSON, A.T. Ecological niche and potential geographic distribution of the invasive fruit fly Bactrocera invadens (Diptera, Tephritidae). Bulletin of Entomological Research, Cambridge, v.100, n.1, p. 35-48, 2010.
MONTES, S.M.N.M.; RAGA, A.; SOUZA-FILHO, M.F. Occurrence of fruit flies (Diptera: Tephritidae) in mixed mango orchard in the city of Presidente Prudente, SP, Brazil. Revista Colombiana de Entomologia, Bogotá, v.38, n.2, p.231-237, 2012.

QIN, Y.; PAINI, D.R.; WANG, C.; FANG, Y.; LI, Z. Global establishment risk of economically important fruit fly species (Tephritidae). PloS One, San Francisco, v.10, n.1, p.1-8, 2015.

RAGA, A.; SOUZA-FILHO, M.F.; MACHADO, R.A.; SATO, M.E.; SILOTO, R.C. Host ranges and infestation indices of fruit flies (Tephritidae) and lance flies (Lonchaeidae) in São Paulo State, Brazil. Florida Entomologist, Winter Haven, v.94, n.4, p. 787-794, 2011.

SÁ, R.F.; CASTELLANI, M.A.; NASCIMENTO, A.S.; BRANDÃO, M.H.S.T.; SILVA, A.N.; PEREZ-MALUF, R. Índice de infestação e diversidade de moscas-das-frutas em hospedeiros exóticos e nativos no pólo de fruticultura de Anagé, BA. Bragantia, Campinas, v.67, n.2, p.401411, 2008.

SÁ, R.F.; CASTELLANI, M.A.; RIBEIRO, A.E.L.; PEREZ-MALUF, R.; MOREIRA, A.A.; NAGAMOTO, N.S.; NASCIMENTO, A.S. Faunal analysis of the species Anastrepha in the fruit growing complex Gavião River, Bahia, Brazil. Bulletin of Insectology, Bologna, v.65, n.1, p. 37-42, 2012.

SILVA, J.G.; DUTRA, V.S.; SANTOS, M.S.; SILVA, N.M.O.; VIDAL, D.B.; NINK, R.A.; GUIMARÃES, J.A.; ARAUJO, E.L. Diversity of Anastrepha spp. (Diptera: Tephritidae) and associated braconid parasitoids from native and exotic hosts in Southeastern Bahia, Brazil. Environmental Entomology, Annapolis, v.39, n.5, p.1457-1465, 2010.

SILVEIRA NETO, S.; NAKANO, O.; BARBIN, D.; VILLA NOVA, N.A. Manual de ecologia dos insetos. São Paulo: Ceres, 1976. p.419.

SZYNISZEWSKA, A.M.; TATEM, A.J. Global assessment of seasonal potential distribution of Mediterranean fuit fly, Ceratitis capitata (Diptera: Tephritidae). PloS One, San Francisco v.9, n.11, p.1-13, 2014.

VILLIERS, M.D.; MANRAKHAN, A.; ADDISON, P.; HATTINGH, V. The distribution, relative abundance, and seasonal phenology of Ceratitis capitata, Ceratitis rosa, and Ceratitis cosyra (Diptara: Tephritidae) in South Africa. Environmental Entomology, Annapolis, v.42, n. 5 , p.831-840, 2013. 
ZUCCHI, R.A. Fruit flies in Brazil: Anastrepha species and their hosts plants. Piracicaba: ESALQ. Disponível $\mathrm{em}$ : http://www.lea.esalq.usp.br/anastrepha. Acesso em: 18 jul. 2017.
ZUCCHI, R.A. Mosca-do-mediterrâneo, Ceratitis capitata (Wiedemann). In: VILELA, E.F; ZUCCHI, R.A. Pragas introduzidas no Brasil: insetos e ácaros. Piracicaba: FEALQ, 2015. p.153-172. 